\title{
Renal Function in Rats with Unilateral Proteinuria Produced by Renal Perfusion with Aminonucleoside
}

\author{
MANJU CHANDRA. ${ }^{(29)}$ JOHN R. HOYER, AND JOHN E. LEWY \\ Department of Pediatrics, Cornell University Medical College-New York Hospital, New York, New York, USA
}

\begin{abstract}
Summary
Left $(L)$ renal perfusion with an aminonucleoside of puromycin $(P A)$, was used to produce unilateral proteinuria in 15 rats to examine the mechanisms responsible for renal salt retention in the nephrotic syndrome. Thirteen control rats underwent $L$ renal perfusion with isotonic saline. Animals were studied 8 (group I) or 13 (group II) days after perfusion. Renal perfusion with saline per se did not change the glomerular filtration rate, renal plasma flow, or absolute and fractional excretion of sodium ( $\mathrm{Na}$ ) from the perfused kidney. PA animals showed a significant decrease in glomerular filtration rate from the perfused kidney and a proportional decrease in the absolute excretion of $\mathrm{Na}$ from the PA perfused kidney as compared to the right kidney. The fractional excretion of $\mathrm{Na}$ was equivalent in the $\mathrm{L}$ and $\mathrm{R}$ kidneys of the PA animals. The mean absolute $\mathrm{Na}$ excretion from the nonproteinuric $R$ kidney of PA rats was almost twice that of the $R$ kidney of the controls. The increased $\mathrm{Na}$ excretion by the nonproteinuric kidney of the PA animals compensated for the sodium retention by the proteinuric kidney.
\end{abstract}

\section{Speculation}

In rats with unilateral proteinuria, unilateral sodium retention occurs due to mechanisms intrinsic to the proteinuric kidney. Systemic natriuretic factors may compensate for the unilateral sodium retention when contralateral kidney is nonproteinuric. When both kidneys are proteinuric, systemic counterbalancing events may not be operative and net sodium retention may result.

The genesis of salt and water retention in the human and experimental nephrotic syndrome appears to involve a complex interaction of multiple factors $(9,13)$. In the pathogenesis of the salt retention in the nephrotic syndrome, a central role is generally assigned to the albumin deficit and fall in the plasma oncotic pressure which may tend to reduce the effective plasma volume, cardiac output, and blood pressure. The resultant baroreceptor stimulation and activation of the sympathetic nervous system, fall in the glomerular plasma flow and glomerular filtration rate (GFR), rise in renin-angiotensin-aldosterone and antidiuretic hormone, and potential decline in the natriuretic humoral factors all tend to encourage renal retention of sodium and water, most likely through enhancement of tubular reabsorption in the distal tubule and the collecting duct segments of the nephron $(9,13,15,19,20)$.

In the human nephrotic syndrome and the experimental models of the nephrotic syndrome, both kidneys are affected by the disease process. It thus becomes difficult to ascertain the relative role of systemic as opposed to intrarenal factors in the alteration of sodium homeostasis. Hoyer et al. (11) have described the technique of producing unilateral proteinuria in rats by selectively perfusing the left renal artery with an aminonucleoside of puromycin (PA). This chemical appears to cause proteinuria by direct renal effect $(12,25)$. Several studies have examined the morphologic changes in the kidney and alterations of glomerular function after acute parenteral administration of PA $(2,5,7,14,21)$.

The present study was designed to examine the function of a proteinuric and a normal kidney in the same milieu to evaluate the mechanisms responsible for renal salt retention. The rat model of Hoyer et al. (11) was used because the morphologic changes observed in the PA perfused kidney in these rats are minimal, and the contralateral kidney shows no morphologic abnormalities. GFR, renal plasma flow (RPF), filtration fraction, absolute and fractional sodium, and potassium excretion and urinary albumin excretion were determined in each kidney 1 or 2 wk after the perfusion.

\section{MATERIALS AND METHODS}

Male Sprague-Dawley albino rats weighing 175 to $250 \mathrm{~g}$ were used. The left renal artery of 15 rats (PA group) was selectively perfused with $60 \mathrm{mg} / \mathrm{kg}$ body weight of aminonucleoside of puromycin, 6-dimethyl amino-9-(3'-amino-3-deoxy)- $\beta$-D-ribofuranosyl)purine. Thirteen rats underwent left renal perfusion with isotonic saline (control group).

\section{LEFT RENAL PERFUSION}

The technique of unilateral renal perfusion described by Hoyer et al. was used. Rats were anesthesized with ether, and the abdominal cavity was exposed through a midline incision. The vessels of the left kidney were isolated from the systemic circulation, and a Lee micro vascular clamp was applied on the aorta. Normal saline or saline solution containing PA in a concentration of $10 \mathrm{mg} / \mathrm{ml}(1.5 \mathrm{ml})$ was injected in the left renal artery over a 15 to $20 \mathrm{sec}$ period. Seven min later, the kidney was reperfused with $4 \mathrm{ml}$ of saline, and the holes in the aorta and renal vein were repaired. The effluent from the renal vein was absorbed by $4 \times 4$ cotton gauze sponges to avoid systemic exposure to the solution used. The renal vascular clamp was removed after a left renal ischemia time of exactly $15 \mathrm{~min}$. The abdomen was closed in two layers.

The animals were placed in individual balance cages. Their weight, urinary output, urinary protein excretion, and urinary sodium and potassium excretion was monitored in the $24 \mathrm{hr}$ before the left renal perfusion and in the $24 \mathrm{hr}$ before the final renal function study. The data of the urinary protein and electrolyte excretion represent this $24-\mathrm{hr}$ period in the unanesthetized rat (Tables 1 and 3 ). One group of rats both control (nine rats) and PA (10 rats) were studied 8 days after perfusion (group I), whereas a second group (group II) was studied 13 days after perfusion with saline (four rats) or PA (five rats).

\section{RENAL FUNCTION STUDY}

Renal function was studied in the antidiuretic and diuretic state. Anesthesia was induced by intraperitoneal injection of 80 to 100 $\mathrm{mg} / \mathrm{kg}$ body weight of Inactin (Promonta, Hamburg, West Ger- 
many). Left and right external jugular veins and trachea were cannulated. The ureters were cannulated with PE no. 10 tubing, and urine from each kidney was collected under mineral oil. Normal saline (1\% of body weight) was injected intravenously over $10 \mathrm{~min}$ to replace surgical fluid losses. This was followed by infusion of normal saline at a rate of $0.04 \mathrm{ml} / \mathrm{min}$. This fluid contained ${ }^{14} \mathrm{C}$-labeled inulin and $p$-aminohippurate (PAH) in sufficient quantities to deliver $30 \mu \mathrm{Ci}\left[{ }^{14} \mathrm{C}\right]$ inulin per $\mathrm{hr}$ and to maintain a plasma level of PAH of 3 to $5 \mathrm{mg} / \mathrm{dl}$. At least $30 \mathrm{~min}$ were allowed for equilibration in the extracellular fluid before beginning the urine collection. Three serial clearance periods of 30 to $60 \mathrm{~min}$ were obtained. Mannitol $(0.25 \mathrm{~g} / \mathrm{kg}$ body weight $)$ was then administered intravenously as a bolus, and mannitol $(0.25 \mathrm{~g} / \mathrm{kg})$ was continued as an infusion over the next $60 \mathrm{~min}$. Three further clearance periods were obtained. Blood samples (approximately $100 \mu \mathrm{l}$ ) were taken from the warmed tail vein during the course of the urine collection periods. Blood was obtained from each renal vein and the heart at the completion of the experiment for calculation of the extraction of PAH.

GFR was estimated with $\left[{ }^{14} \mathrm{C}\right]$ inulin carboxylic acid analyzed in a Packard Tri-carb liquid scintillation counter. p-Aminohippurate was analyzed colorimetrically by a microadaptation of the method of Bratten and Marshall, as modified by Smith (10). RPF was calculated from the PAH clearance and PAH extraction $\left({ }^{\mathrm{C}} \mathrm{PAH} \div{ }^{\mathrm{E}} \mathrm{PAH}\right)$. Filtration fraction was calculated by dividing GFR by RPF. Total protein in the serum was determined by a modification of the method of Lowry et al. (17). Serum albumin and quantitative urinary albumin excretion were measured by single radial immunodiffusion using monospecific rabbit antisera to rat albumin (18). Urine and serum sodium and potassium were estimated by flame photometry in an autoanalyser.

Paired $t$ tests were used to test the null hypothesis that in both control and PA perfused rats there was no difference between left and right kidney function. The significance of the effect of PA administration over and above that of the effect of perfusion was determined by contrasting mean differences in kidney function (left-right kidney) in the PA and control groups. $P$ values were computed from the $t$ value derived from the formula $\bar{D}_{C}-$ $\overline{\mathrm{D}}_{\mathrm{PA}} / \hat{\mathbf{S}}_{\overline{\mathrm{D}}_{\mathrm{c}}}-\overline{\mathrm{D}}_{\mathrm{PA}}$ where $\overline{\mathrm{D}}_{\mathrm{c}}$ and $\overline{\mathrm{D}}_{\mathrm{PA}}$ are mean differences in left and right kidney function in the control and PA groups, respectively, and $\hat{S}_{\bar{D}_{r}}-\overline{\mathrm{D}}_{\mathrm{PA}}$ is estimate of standard error of the contrast between mean differences in the PA and control groups. The 0.05 level of probability two tailed) was used as the criteria of significance.

\section{RESULTS}

\section{GROUP I RATS (RATS STUDIED 8 DAYS AFTER LEFT RENAL} PERFUSION)

Table 1 illustrates the clinical features of the group $I$ rats. The urinary albumin excretion before perfusion was similar in control and PA rats. After 8 days, the mean urinary albumin excretion was unchanged in the controls, but in PA animals, it rose to 28.4 $\pm 5.7 \mu \mathrm{g} / \mathrm{min}$. The albumin excretion from the right ureter was similar in control and in PA animals $(1.5 \mu \mathrm{g} / \mathrm{min}$ in control versus $1.0 \mu \mathrm{g} / \mathrm{min}$ in PA). Thus, most of the urinary albumin excreted by PA rats was contributed by the left kidney. The slightly increased right ureteral albumin excretion as compared to the basal albumin excretion measured in the 24-hr urine in both control and PA animals may be attributed to catheter damage to the ureter with resultant exudation of plasma. Albumin excretion from the left kidney was not measured because of insufficient volume of urine obtained. Serum albumin was significantly lower in PA animals $(1.81 \pm 0.13 \mathrm{~g} / \mathrm{dl})$ as compared to controls $(2.17 \pm 0.14 \mathrm{gm} / \mathrm{dl} ; P$ $<0.05$ ). Urinary sodium and potassium excretion before and after perfusion were not different in the two groups.

Table 2 tabulates observations of individual kidney function. In the control rats, the left and right kidney function was similar in reference to GFR, RPF, filtration fraction, and absolute and fractional excretion of sodium. Absolute and fractional excretion of potassium was higher from the perfused kidney. The fractional excretion of $\mathrm{Na}$ is reported as $\mathrm{U}_{\mathrm{Na}} \mathrm{V} / \mathrm{GFR}, \mu \mathrm{Eq} / \mathrm{min} \cdot 100 \mu \mathrm{lGFR}$. In the PA animals, the overall GFR was almost one-half of that in the controls ( 810 versus $1529 \mu \mathrm{l} / \mathrm{min} \cdot \mathrm{g}$ kidney). GFR was also significantly decreased in the PA perfused side when compared to the right kidney of the same animal or to the difference in GFR between the two kidneys in the control group, both in the antidiuretic and the diuretic state. The absolute sodium excretion $\left(\mathrm{U}_{\mathrm{Na}} \mathrm{V}\right)$ from PA perfused left kidney was significantly decreased as compared to the right side $(P<0.025)$. The $\mathrm{U}_{\mathrm{Na}} \mathrm{V}$ from the nonperfused right kidney of PA animals $(0.183 \pm 0.05 \mu \mathrm{Eq} / \mathrm{min})$ was twice that of the right kidney of the control animals $(0.096 \pm 0.03$ $\mu \mathrm{Eq} / \mathrm{min}$ ). Despite a lower overall GFR in PA animals, the absolute sodium excretion of the PA animals was not different from that of the controls $(0.234 \mu \mathrm{Eq} / \mathrm{min}$ in PA versus $0.231 \mu \mathrm{Eq} /$ $\mathrm{min}$ in controls). The fractional excretion of sodium and potassium was proportional to their filtered load in both kidneys of the PA animals. Renal plasma flow and filtration fraction were decreased in the PA perfused kidney when compared to the right kidney of the same animal.

\section{GROUP II RATS (RATS STUDIED I3 DAYS AFTER LEFT RENAL PERFUSION)}

Table 3 illustrates the biochemical data. Thirteen days after perfusion, the urinary albumin was unchanged in controls, but in PA animals it rose to $50.3 \pm 7.9 \mu \mathrm{g} / \mathrm{min}$ and was higher than that observed 8 days after perfusion $(28.4 \pm 5.7 \mu \mathrm{g} / \mathrm{min})$. The albumin excretion from the right and left ureters was similar in controls, whereas in PA animals most of the albumin was contributed by the left kidney. However, the albumin excretion from the right ureter of PA animals was higher $(5.6 \pm 2.3 \mu \mathrm{g} / \mathrm{min})$ than in the right ureter of controls $(1.2 \pm 0.2 \mu \mathrm{g} / \mathrm{min})$. This may represent

Table 1. Clinical features of group I control and aminonucleoside rats studied 8 days after perfusion

\begin{tabular}{|c|c|c|c|c|}
\hline & \multicolumn{2}{|c|}{ Control } & \multicolumn{2}{|c|}{ PA } \\
\hline & Preperfusion & Final & Preperfusion & Final \\
\hline No. of animals & 9 & 9 & 10 & 10 \\
\hline Body weight $(\mathrm{g})$ & $212.3 \pm 13.6^{1}$ & $226.3 \pm 16.5$ & $216.2 \pm 12.6$ & $222.4 \pm 11.7$ \\
\hline Urine albumin $(\mu \mathrm{g} / \mathrm{min})(24-\mathrm{hr}$ urine $)$ & $0.21 \pm 0.03$ & $0.24 \pm 0.07$ & $0.22 \pm 0.04$ & $28.4 \pm 5.7$ \\
\hline Urine albumin $(\mu \mathrm{g} / \mathrm{min})$ (right ureter) & & $1.5 \pm 0.3$ & & $1.0 \pm 0.2$ \\
\hline Urine sodium $(\mu \mathrm{Eq} / \mathrm{min})$ & $0.38 \pm 0.08$ & $0.46 \pm 0.11$ & $0.43 \pm 0.08$ & $0.51 \pm 0.08$ \\
\hline Urine potassium $(\mu \mathrm{Eq} / \mathrm{min})$ & $0.86 \pm 0.21$ & $1.27 \pm 0.27$ & $1.03 \pm 0.14$ & $1.24 \pm 0.18$ \\
\hline Serum total protein $(\mathrm{g} / \mathrm{dl})$ & & $5.69 \pm 0.25$ & & $4.99 \pm 0.29$ \\
\hline Serum albumin $(\mathrm{g} / \mathrm{dl})$ & & $2.17 \pm 0.14$ & & $1.81 \pm 0.13^{2}$ \\
\hline Hematocrit & & $50.2 \pm 0.8$ & & $48.4 \pm 0.9$ \\
\hline Serum sodium (mEq/liter) & & $148.5 \pm 1.6$ & & $148.2 \pm 1.3$ \\
\hline Serum potassium (mEq/liter) & & $5.5 \pm 1.5$ & & $4.6 \pm 0.3$ \\
\hline
\end{tabular}

${ }^{1}$ Mean \pm S.E.

${ }^{2} P<0.05$, PA versus control using students $t$ test. 
some exposure of the nonperfused right kidney to the aminonucleoside which may have inadvertently reached there via the systemic circulation. There was no significant difference in the serum albumin, serum total protein, serum sodium and potassium, or hematocrit between these two groups.

Table 4 tabulates observations of renal function of rats 13 days after perfusion. In the control rats, GFR, RPF, filtration fraction, and the absolute and fractional excretion of sodium were similar in the perfused and the nonperfused kidneys. Absolute excretion of potassium was higher from the perfused side. In the PA animals, the GFR of the left kidney was significantly decreased as compared to right kidney of the same animal and the difference in GFR between the two kidneys of control group, in the antidiuretic state. Absolute excretion of sodium and potassium was significantly decreased in the PA perfused left kidney as compared to the right. The mean $\mathrm{U}_{\mathrm{Na}} \mathrm{V}$ from the right kidney of $\mathrm{PA}$ group $(0.364 \pm 0.09 \mu \mathrm{Eq} / \mathrm{min})$ was almost twice that of the right kidney of the control animals $(0.177 \pm 0.05 \mu \mathrm{Eq} / \mathrm{min})$. The fractional excretion of both sodium and potassium was equivalent in the left and right kidneys of the PA animals, and the difference in the absolute excretion of $\mathrm{Na}$ and $\mathrm{K}$ was relative to the filtered load. Despite a lower overall GFR (1129 $\mu \mathrm{l} / \mathrm{min} \cdot \mathrm{g}$ kidney PA versus $1920 \mu \mathrm{l} / \mathrm{min} \cdot \mathrm{g}$ kidney in controls), the absolute sodium excretion of the PA animals was equivalent to that of the controls. The filtration fraction of the PA perfused left kidney was decreased as compared to the right kidney of the same animal.

Table 2. Right and left kidney function of group I control and aminonucleoside rats

\begin{tabular}{|c|c|c|c|c|c|c|c|c|c|}
\hline & \multicolumn{4}{|c|}{ Control } & \multicolumn{5}{|c|}{ PA } \\
\hline & Left & Right & $\begin{array}{c}\text { Left }+ \\
\text { right }\end{array}$ & $P^{1}$ & Left & Right & $\begin{array}{c}\text { Left }+ \\
\text { right }\end{array}$ & $\begin{array}{l}P^{\prime}(\text { Left - } \\
\text { right })\end{array}$ & $\begin{array}{l}P^{1}(\text { Left - } \\
\text { right) })^{2}- \\
(\text { left - } \\
\text { right })_{P A}\end{array}$ \\
\hline No. of animals & 9 & 9 & & & 10 & 10 & & & \\
\hline Kidney wt (g) & $1.03 \pm 0.06^{.1}$ & $1.02 \pm 0.06$ & 2.05 & NS & $1.18 \pm 0.06$ & $1.18 \pm 0.06$ & 2.36 & NS & NS \\
\hline \multicolumn{10}{|l|}{ Antidiuretic state } \\
\hline $\begin{array}{l}\mathrm{C}_{\text {In }}(\mu \mathrm{l} / \mathrm{min} \cdot \mathrm{g} \text { kid- } \\
\text { ney) }\end{array}$ & $799 \pm 51$ & $730 \pm 62$ & $1529^{4}$ & NS & $241 \pm 91$ & $569 \pm 110$ & $810^{4}$ & $<0.005$ & $<0.001$ \\
\hline $\begin{array}{l}\mathrm{C}_{\text {PAH }}(\mu \mathrm{l} / \mathrm{min} \cdot \mathrm{g} \\
\text { kidney) }\end{array}$ & $2030 \pm 90$ & $1983 \pm 189$ & $4013^{4}$ & $<0.01$ & $1499 \pm 610$ & $2138 \pm 234$ & $3637^{4}$ & NS & $<0.05$ \\
\hline $\mathrm{U}_{\mathrm{Na}} \mathrm{V}(\mu \mathrm{Eq} / \mathrm{min})$ & $0.135 \pm 0.07$ & $0.096 \pm 0.03$ & 0.231 & NS & $0.051 \pm 0.01$ & $0.183 \pm 0.05$ & 0.234 & $<0.025$ & $<0.01$ \\
\hline $\begin{array}{l}\mathrm{U}_{\mathrm{Nu}} \mathrm{V} / \mathrm{GFR} \\
\quad(\mu \mathrm{Eq} / \mathrm{min} \cdot 100 \\
\mu \mathrm{l} \mathrm{GFR})\end{array}$ & $0.015 \pm 0.01$ & $0.012 \pm 0.004$ & & NS & $0.025 \pm 0.08$ & $0.027 \pm 0.006$ & - & NS & NS \\
\hline $\mathrm{U}_{\mathrm{k}} \mathrm{V}(\mu \mathrm{Eq} / \mathrm{min})$ & $0.458 \pm 0.09$ & $0.357 \pm 0.07$ & 0.815 & $<0.05$ & $0.347 \pm 0.14$ & $0.707 \pm 0.14$ & 1.054 & NS & $<0.01$ \\
\hline $\begin{array}{l}\mathrm{U}_{\mathrm{k}} \mathrm{V} / \mathrm{GFR}(\mu \mathrm{Eq} / \\
\min \cdot 100 \mu \mathrm{l} \\
\mathrm{GFR})\end{array}$ & $0.061 \pm 0.01$ & $0.051 \pm 0.01$ & & NS & $0.113 \pm 0.01$ & $0.107 \pm 0.02$ & - & NS & NS \\
\hline \multicolumn{10}{|l|}{ Diuretic state } \\
\hline $\begin{array}{l}\mathrm{C}_{\text {In }}(\mu \mathrm{l} / \mathrm{min} \cdot \mathrm{g} \text { kid- } \\
\text { ney) }\end{array}$ & $918 \pm 155$ & $767 \pm 20$ & $1685^{4}$ & NS & $287 \pm 64$ & $648 \pm 66$ & $965^{4}$ & $<0.001$ & $<0.005$ \\
\hline $\begin{array}{l}\mathrm{C}_{\text {Y'AH }}(\mu \mathrm{l} / \mathrm{min} \cdot \mathrm{g} \\
\text { kidney) }\end{array}$ & $1930 \pm 192$ & $1833 \pm 189$ & $3763^{4}$ & NS & $1671 \pm 325$ & $2081 \pm 190$ & $3752^{4}$ & NS & $<0.05$ \\
\hline $\begin{array}{l}\mathrm{RPF}(\mu \mathrm{l} / \mathrm{min} \cdot \mathrm{g} \\
\text { kidney })\end{array}$ & $2106 \pm 62$ & $2114 \pm 153$ & $4220^{4}$ & NS & $1990 \pm 305$ & $2780 \pm 389$ & $4770^{4}$ & $<0.025$ & $<0.01$ \\
\hline Filtration fraction & $0.40 \pm 0.02$ & $0.36 \pm 0.01$ & - & NS & $0.12 \pm 0.01$ & $0.24 \pm 0.03$ & & $<0.005$ & $<0.001$ \\
\hline
\end{tabular}

'See text for derivation of $P$ value

"C. Control: PA, aminonucleoside perfused: NS, not significant.

- 3 Mean \pm S.E.

${ }^{4}$ Data expressed as $\mu \mathrm{l} / \mathrm{min} \cdot \mathrm{g}$ kidney, for two kidneys.

Table 3. Clinical Features of group II control and aminonucleoside rats studied 13 davs after perfusion

\begin{tabular}{|c|c|c|c|c|}
\hline & \multicolumn{2}{|c|}{ Control } & \multicolumn{2}{|c|}{ PA } \\
\hline & Preperfusion & Final & Preperfusion & Final \\
\hline No. of animals & 4 & 4 & 5 & 5 \\
\hline Body wt. & $209 \pm 15^{\prime}$ & $251 \pm 15$ & $209 \pm 9$ & $243 \pm 8$ \\
\hline Urinary albumin $(\mu \mathrm{g} / \mathrm{min})$ & $0.15 \pm 0.06$ & $0.13 \pm 0.06$ & $0.15 \pm 0.01$ & $50.3 \pm 7.9$ \\
\hline Urine albumin ( $\mu \mathrm{g}$ right ureter $)$ & & $1.2 \pm 0.2$ & & $5.6 \pm 2.3$ \\
\hline Urine albumin ( $\mu \mathrm{g}$ left ureter) & & $1.3 \pm 0.8$ & & $33.3 \pm 11.1$ \\
\hline Serum total protein $(\mathrm{g} / \mathrm{dl})$ & & $5.93 \pm 0.29$ & & $5.5 \pm 0.09$ \\
\hline Serum albumin $(\mathrm{g} / \mathrm{dl})$ & & $1.99 \pm 0.32$ & & $1.84 \pm 0.23$ \\
\hline Hematocrit & & $47.5 \pm 0.9$ & & $46 \pm 0.8$ \\
\hline Serum sodium (mEq/liter) & & $147 \pm 1.8$ & & $150 \pm 1.16$ \\
\hline Serum potassium (mEq/liter) & & $5.4 \pm 0.2$ & & $5.2 \pm 0.15$ \\
\hline
\end{tabular}

Mean \pm S.E 
RENAL FUNCTION IN RATS WITH UNILATERAL PROTEINURIA

Table 4. Right and left kidney function of group II control and aminonucleoside rats

\begin{tabular}{|c|c|c|c|c|c|c|c|c|c|}
\hline & \multicolumn{4}{|c|}{ Control } & \multicolumn{3}{|c|}{ PA } & \multirow{2}{*}{$\begin{array}{l}P^{\prime} \text { (Left } \\
- \text { right) }\end{array}$} & \multirow{2}{*}{$\begin{array}{c}P^{\prime} \text { (Left } \\
- \\
\text { right) } \\
-(\text { left }- \\
\text { right) }{ }^{2} \cdot{ }^{\prime}\end{array}$} \\
\hline & Left & Right & $\begin{array}{c}\text { Left }+ \\
\text { right }\end{array}$ & $\begin{array}{l}P^{\prime} \text { (Left } \\
- \text { right) }\end{array}$ & Left & Right & $\begin{array}{c}\text { Left }+ \\
\text { right }\end{array}$ & & \\
\hline No. of animals & 4 & 4 & & & 5 & 5 & & & \\
\hline Kidney wt (g) & $1.15 \pm 0.13^{3}$ & $1.12 \pm 0.06$ & 2.27 & NS & $1.32 \pm 0.12$ & $1.38 \pm 0.13$ & 2.70 & NS & NS \\
\hline \multicolumn{10}{|l|}{ Antidiuretic state } \\
\hline $\begin{array}{l}\mathrm{C}_{\text {In }}(\mu \mathrm{l} / \mathrm{min} \cdot \mathrm{g} \text { kid- } \\
\text { ney) }\end{array}$ & $1016 \pm 25$ & $904 \pm 29$ & $1920^{4}$ & NS & $370 \pm 96$ & $759 \pm 147$ & $1129^{4}$ & $<0.05$ & $<0.005$ \\
\hline $\begin{array}{l}\mathrm{C}_{\text {PAH }}(\mu \mathrm{l} / \mathrm{min} \cdot \mathrm{g} \\
\text { kidney) }\end{array}$ & $2668 \pm 445$ & $2238 \pm 481$ & $4906^{4}$ & $<0.01$ & $2261 \pm 637$ & $2579 \pm 497$ & $4840^{4}$ & NS & $<0.005$ \\
\hline $\mathrm{U}_{\mathrm{N} \mathrm{s}} \mathrm{V}(\mu \mathrm{Eq} / \mathrm{min})$ & $0.297 \pm 0.10$ & $0.177 \pm 0.05$ & 0.474 & NS & $0.152 \pm 0.04$ & $0.364 \pm 0.09$ & 0.516 & 0.05 & $<0.01$ \\
\hline $\begin{array}{l}\mathrm{U}_{\mathrm{Na}} \mathrm{V} / \mathrm{GFR}(\mu \mathrm{Eq} / \\
\min \cdot 100 \mu \mathrm{l} \\
\mathrm{GFR})\end{array}$ & $0.025 \pm 0.008$ & $0.018 \pm 0.004$ & & NS & $0.030 \pm 0.004$ & $0.036 \pm 0.006$ & & NS & NS \\
\hline $\mathrm{U}_{\mathrm{k}} \mathrm{V}(\mu \mathrm{Eq} / \mathrm{min})$ & $0.713 \pm 0.09$ & $0.503 \pm 0.07$ & 1.216 & $<0.05$ & $0.316 \pm 0.07$ & $0.756 \pm 0.18$ & 1.081 & $<0.05$ & $<0.005$ \\
\hline $\begin{array}{l}\mathrm{U}_{\mathrm{k}} \mathrm{V} / \mathrm{GFR}(\mu \mathrm{Eq} / \\
\min \cdot 100 \mu \mathrm{l} \\
\mathrm{GFR})\end{array}$ & $0.061 \pm 0.01$ & $0.051 \pm 0.01$ & & NS & $0.072 \pm 0.01$ & $0.084 \pm 0.02$ & & NS & NS \\
\hline \multicolumn{10}{|l|}{ Diuretic state } \\
\hline $\begin{array}{l}\mathrm{C}_{\mathrm{In}}(\mu \mathrm{l} / \mathrm{min} \cdot \mathrm{g} \text { kid- } \\
\text { ney) }\end{array}$ & $708 \pm 87$ & $735 \pm 67$ & $1443^{4}$ & NS & $367 \pm 124$ & $895 \pm 272$ & $1263^{4}$ & $<0.05$ & NS \\
\hline $\begin{array}{l}\mathrm{C}_{\text {PAH }}(\mu \mathrm{l} / \mathrm{min} \cdot \mathrm{g} \\
\text { kidney })\end{array}$ & $2197 \pm 463$ & $2292 \pm 335$ & $4489^{4}$ & NS & $1929 \pm 588$ & $2805 \pm 543$ & $4734^{4}$ & NS & NS \\
\hline $\begin{array}{l}\text { RPF }(\mu \mathrm{l} / \mathrm{min} \cdot \mathrm{g} \\
\text { kidney) }\end{array}$ & $3356 \pm 304$ & $3214 \pm 490$ & $6570^{4}$ & NS & $2406 \pm 54$ & $3019 \pm 198$ & $5076^{4}$ & NS & NS \\
\hline Filtration fraction & $0.20 \pm 0.01$ & $0.23 \pm 0.01$ & & NS & $0.18 \pm 0.02$ & $0.31 \pm 0.03$ & & $<0.01$ & $<0.01$ \\
\hline
\end{tabular}

\section{DISCUSSION}

This study demonstrates that unilateral renal perfusion with PA produced marked proteinuria only from the perfused side as documented by the measurement of ureteral albumin concentration from each side. This confirms the observation of Hoyer $e t$ al. (11) who in this animal model demonstrated a prompt fall in protein excretion to normal levels after removal of the perfused kidney. Previous studies in rats with aminonucleoside nephrosis have suggested that the proteinuria observed in this model is primarily of glomerular origin $(3,16,23)$. Bohrer et al. (3) using fractional clearance of uncharged dextran and polyanionic dextran sulfate, provided evidence that in rats with PA nephrosis there is no increase in effective pore radius or number of pores, but the proteinuria results from the diminution of the electrostatic barrier function of the glomerular capillary wall, thereby allowing increased passage of polyanions such as dextran sulfate and albumin.

We observed that rats with unilateral perfusion of PA did not show decrease in serum protein to the same extent as the rats who were given PA parenterally and who show comparable degree of proteinuria $(11,15)$. However, the urinary albumin excretion of $50.3 \pm 7.9 \mu \mathrm{g} / \mathrm{min}$ was reached on the 13 th day in our rats, whereas the rats with intravenous administration of PA showed urine protein excretion of $58.0 \pm 9.2 \mu \mathrm{g} / \mathrm{min}$ on the sixth day (15). A significant decrease in serum albumin in our study was observed only in group I PA animals, although the group II PA rats developed almost twice the amount of proteinuria. This suggests that in our rats, hypoproteinemia may be averted by increased albumin synthesis by the liver, with the stimulus of continued proteinuria (8).

The data demonstrate that unilateral renal perfusion with saline with a kidney ischemia time of $15 \mathrm{~min}$ does not alter albumin excretion, GFR, RPF, filtration fraction, or absolute and fractional excretion of sodium from the perfused as compared to the nonperfused side (Tables 2 and 4). On the other hand, unilateral renal perfusion with PA results in a significant decrease in GFR of the perfused kidney (Tables 2 and 4 ). No compensatory increase in GFR was present in the nonperfused kidney of the PA animal. Bohrer et al. (13) reported that the decrease in the total kidney GFR and single nephron GFR in the PA-treated Munich Wistar rats appeared to be primarily due to a fall in the glomerular capillary ultra filtration coefficient, and to a lesser extent, to a small reduction in glomerular plasma flow rate as well. The lack of a compensatory increase in GFR in the contralateral kidney of PA perfused animals is unexplained. It is possible that a small amount of PA leaked into the systemic circulation during the perfusion and caused changes in the filtration dynamics in the contralateral kidney, but this remains unproven.

RPF was significantly decreased in the PA perfused kidney of group I rats as compared to the saline perfused kidney. Oken $e t$ al. (23), reported a decrease in renal cortical blood flow in PA injected rats, and Banks et al. (1) demonstrated a decrease in the ratio of outer to inner cortical blood flow 6 days after PA injection. Bohrer et al. (3) also found a reduction in glomerular plasma flow rate averaging about $20 \%$ in the PA-treated rats (3).

The absolute excretion of sodium from the PA perfused kidney was decreased as compared to the nonperfused kidney in both group I and group II animals. This decrease was proportional to the decrease in the filtered load. It is noteworthy that the nonperfused right kidney of the PA animals had almost twice the mean absolute sodium excretion as the right kidney of the control animals (Tables 2 and 4). Thus, the right kidney of PA animals demonstrates compensation for the decrease in absolute sodium excretion of the PA perfused left kidney. Hence, despite a decrease 
in GFR, the sodium excretion of PA animals both under anesthesia and in the awake state was equivalent to that of controls. Decreased filtration fraction observed in the left kidney of both group I and group II PA rats may have resulted in an increase in fractional sodium excretion from the left kidney because decreased filtration fraction is known to be associated with decrease in proximal tubular reabsorption of sodium chloride (24). However, the natriuresis observed in the nonproteinuric kidney of both group I and group II PA rats suggests the influence of systemic factors on tubular reabsorption of sodium. Systemic factors which may be considered as responsible for the natriuresis in the PA rats include the hypothetical natriuretic hormone $(4,6)$, inhibition of aldosterone secretion, and systemic hypertension (22). Further studies in this model are needed to evaluate the role of these systemic factors.

This study demonstrates that in rats with marked unilateral proteinuria, unilateral sodium retention occurs due to mechanisms intrinsic to the proteinuric kidney. The data suggest that unilateral sodium retention by the proteinuric kidney is compensated for by systemic natriuretic factors, when the contralateral kidney is nonproteinuric. When both kidneys are proteinuric, systemic counterbalancing events may not be operative and net sodium retention may result.

\section{REFERENCES AND NOTES}

1. Banks, R. O., Pesce, A. J., Ooi, B. S., and Pollak, V. E.: Effect of aminonucleoside on transport maximum of para-aminohippurate and intrarenal blood flow distribution in rats. J. Lab. Clin. Med., 90: 341 (1977).

2. Blau, E. B., and Michael, A. F.: Rat glomerulus glycoprotein composition and metabolism in aminonucleoside nephrosis. Proc. Soc. Exp. Biol. Med., 141: 164 (1972)

3. Bohrer, M. P., Baylis, C., Robertson. C. R., and Brenner, B. M.: Mechanism of the puromycin-induced defects in the transglomerular passage of water and macromolecules. J. Clin. Invest., 60: 152 (1977).

4. Bourgoignie. J. J., Hwang, K. H., Ipakchi, E., and Bricker, N. S.: The presence of a natriuretic factor in urine of patients with chronic uremia: the absence of the factor in nephrotic uremic patients. J. Clin. Invest.. 53: 1559 (1974).

5. Caulfield, J. P., Reid, J. J.. and Farquhar, M. G.: Alterations of the glomerular epithelium in acute aminonucleoside nephrosis. Lab. Invest.. 34: 43 (1976).

6. Clarkson, E. M.. Rau, S. M., and de Wardener, H. E.: Two natriuretic substances in extracts of urine from normal man when salt-depleted and salt-loaded. Kidney Int., 10: 381 (1976).

7. Feldman, J. D., and Fisher, E. R.: Renal lesions of aminonucleoside nephrosis as revealed by electron microscopy. Lab. Invest., $8: 371$ (1959).

8. Gitlin, D., Janeway, C. A., and Farr, L. E.: Studies on the metabolism at plasma proteins in the nephrotic syndrome. J. Clin. Invest., 35: 44 (1956).

9. Glassock, R. J.. and Bennett, C. M.: The glomerulopathies. In: B. M. Brenner, F.
C. Rector: The Kidney. Vol. 2, p. 954 (W. B. Saunders Co.. Philadelphia, 1976).

10. Goldring, W., and Chassis, H.: Hypertension and hypertensive disease. Appendix D: Methods. p. 194 (The Commonwealth Fund, New York, 1944).

11. Hoyer, J. R., Mauer, S. M., and Michael, A. F.: Unilateral renal disease in the rat. I. Clinical, morphologic and glomerular mesangial functional features of the experimental model produced by renal perfusion with the aminonucleoside of puromycin. J. Lab. Clin. Med., 85: 756 (1975).

12. Hoyer, J. R., Ratte, J., Potter, A. H., and Michael, A. F.: Transfer of aminonucleoside nephrosis by renal transplantation. J. Clin. Invest., 51: 2777 (1972).

13. Kalant, N., DasGupta. D., Despointes, R., and Giroud, C. J.: Mechanisms of edema in experimental nephrosis. Am. J. Physiol., 202: 91 (1962).

14. Lannigan, P., Kark, R., and Pollak, V. E.: The effect of a single intravenous injection of aminonucleoside of puromycin on the rat kidney: a light and electron microscopy study. J. Pathol. Bacteriol., 83: 357 (1962).

15. Lewy. J. E.: Micropuncture study of fluid transfer in aminonucleoside nephrosis. Pediatr. Res., 10: 30 (1976).

16. Lewy, J. E., and Pesce. A. J.: Micropuncture study of albumin transfer in aminonucleoside nephrosis in the rat. Pediatr. Res.. 7: 553 (1973).

17. Lowry, O. H., Rosenbrough, N. J., Farr, A. L., and Randall, R. J.: Protein measurement with the Folin phenol reagent. J. Biol. Chem., 193: 265 (1951).

18. Mancini, G.. Carbonara, A. O., and Heremans, J. R.: Immunochemical quantitation of antigens by single radial immunodiffusion. Immunochemistry, 2: 235 tation of

19. Medina, A., Davies, D. L., Brown, J. J., Fraser, R., Lever. A. F., Mallick, N. P., Morton, J. J., Robertson. J. I. S., and Tree, M. D.: A study of the reninangiotensin system in the nephrotic syndrome. Nephron, 12: 233 (1974).

20. Metcoff, J., and Janeway, C. A.: Studies on the pathogenesis of nephrotic edema. J. Pediatr. 58: 640 (1961).

21. Nagle, R. B., Bulger, R. E., Striker, G. E., and Benditt, E. P.: Renal tubular effects of the aminonucleoside of puromycin. Lab. Invest.. 26: 558 (1972).

22. Nizet, A., Baerten, A., Dujardin, A., Thoumsin, H., and Thoumsin-Moons, J.: Quantitative infuence of non-hormonal blood factors on the control of sodium excretion by the isolated dog kidney. Kidney Int., 1: 27 (1972).

23. Oken, D. E., Cotes, S. C., and Mende, C. W.: Micropuncture of tubular transport of albumin in rats with aminonucleoside nephrosis. Kidney Int., 1: 3 (1972).

24. Schrier, R. W., and deWarderner, H. E.: Tubular reabsorption of sodium ion: Influence of factors other than aldosterone and glomerular filtration rate. $\mathrm{N}$. Engl. J. Med., 285: 1231 (1971).

25. Yoshida, T., Yamashita, F., and Metcoff, J.: Metabolic basis of aminonucleoside nephrosis in rats. I. Inhibiton of $\mathrm{x}$-oxoglutarate oxidation by aminonucleoside. J. Lab. Clin. Med., 72: 565 (1968).

26. Dr. Hoyer was an established investigator of the American Heart Association during these studies.

27. The present address of Dr. John R. Hoyer is: Department of Pediatrics, Harbor UCLA Medical Center. Torrance, CA 90509

28. The present address of Dr. John E. Lewy, Department of Pediatrics, Tulane University School of Medicine. New Orleans, LA 70112

29. Requests for reprints should be addressed to: Manju Chandra, M.D., Division of Pediatric Nephrology, Department of Pediatrics, North Shore University Hospital, 300 Community Drive. Manhasset. New York 11030 (USA).

pital, 300 Community Drive. Manhasset. New York 11030 (USA).
30. This research was supported in part by NIH training grant HD 00383 .

31. Received for publication March 25, 1980.

32. Accepted for publication August 13, 1980. 